Fetal Diagnosis and Therapy

\title{
Modulation of Free Corticotrophin-Releasing Hormone, Adrenal and Placental Steroid Hormone Levels Induced by Mifepristone during Pregnancy
}

\author{
Pierre-François Ceccaldi ${ }^{a} \quad$ Julien Saada ${ }^{b}$ Mireille Nicolas ${ }^{c}$ Guillaume Ducarme ${ }^{a}$ \\ Philippe Blot $^{\mathrm{b}}$ Jean Guibourdenche ${ }^{d}$ Dominique Luton ${ }^{\mathrm{a}}$ \\ ${ }^{a}$ Department of Obstetrics and Gynecology, AP-HP Beaujon Hospital, Clichy, Departments of ${ }^{b}$ Obstetrics

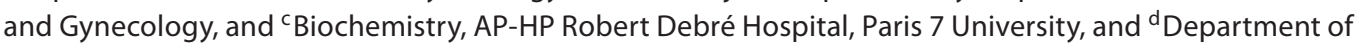 \\ Biochemistry, AP-HP Groupe Hospitalier Cochin and Saint Vincent de Paul, Paris 5 University, Paris, France
}

\section{Key Words}

Parturition $\cdot$ Mifepristone $\cdot$ Progesterone $\cdot$ Cortisol $\cdot$

Corticotrophin-releasing hormone

\begin{abstract}
Mifepristone is a progesterone receptor antagonist widely used in obstetrics. The aim of the study was to focus on free corticotrophin-releasing hormone $(\mathrm{CRH})$ and also describe modulation of adrenal and placental steroid hormone concentrations induced by mifepristone. Methods: Twenty-six women were enrolled in the study. They received mifepristone for termination of pregnancy. Maternal blood samples were retrieved before administration of mifepristone $(600$ $\mathrm{mg}$ ) and $48 \mathrm{~h}$ after, just before induction of labor. Bound and free $\mathrm{CRH}$ levels were determined in maternal blood concomitantly with cortisol, estriol, progesterone and SDHEA levels. Also paired fetal cord blood samples were collected. $\boldsymbol{R e}$ sults: Maternal plasmatic CRH level did not change after mifepristone absorption but free $\mathrm{CRH}$ increased significantly $(0.500 \pm 0.326$ vs. $0.388 \pm 0.303 \mathrm{ng} / \mathrm{ml}, \mathrm{p}=0.040)$. A significant decrease of progesterone was observed (83.6 \pm 49.3 vs. $95.6 \pm 54.9 \mathrm{ng} / \mathrm{ml}, \mathrm{p}=0.001$ ) with a lower progesterone/estriol ratio $(26.9 \pm 15.7$ vs. $40.7 \pm 31.1, p=0.004)$. There was a strong association between maternal and fetal free $\mathrm{CRH}\left(r^{2}=0.675, p=0.001\right)$, cortisol $\left(r^{2}=0.570, p=0.019\right)$, and
\end{abstract}

positive but modest correlation for progesterone $\left(r^{2}=0.341\right.$, $p=0.046)$ and estriol $\left(r^{2}=0.379, p=0.025\right)$ levels. Conclusion: Mifepristone has an effect on free CRH level and changes the estriol-progesterone balance.

Copyright $\odot 2012$ S. Karger AG, Basel

\section{Introduction}

Mifepristone is a progesterone $(\mathrm{P})$ receptor antagonist widely used in obstetrics. It causes cervical ripening and facilitates labor induction with an action on myometrium. Its mechanism of action is actually unclear, may be integrated in the physiologic pathway like the corticotrophin-releasing hormone (CRH), and generate an estrogenic environment at the onset of labor as described Smith et al. [1]. This author has found an association between a rapid rise of $\mathrm{CRH}$ in late pregnancy and an elevation of estriol $\left(\mathrm{E}_{3}\right)$ with decreased $\mathrm{P} / \mathrm{E}_{3}$ ratio.

During gestation, placental CRH circulates in maternal blood mostly bound to $\mathrm{CRH}$-binding protein $(\mathrm{CRH}-$ $\mathrm{BP})$ which is produced by the maternal liver and the placenta [2]. Maternal levels of CRH rise throughout gestation and correlate with the onset of parturition and with some clinical settings, like preeclampsia, where advanced fetal maturation is observed [3]. Studies in human have

\section{KARGER}

Fax +4161306 1234

E-Mail karger@karger.ch

www.karger.com (c) 2012 S. Karger AG, Basel

$1015-3837 / 12 / 0324-0267 \$ 38.00 / 0$

Accessible online at:

www.karger.com/fdt
Prof. Dominique Luton, $\mathrm{MD}, \mathrm{PhD}$

Obstetrics and Gynecology Department, Beaujon Hospital

Assistance Publique Hôpitaux de Paris and Paris 7 University

100, Boulevard du Général Leclerc, FR-92100 Clichy (France)

Tel. +33 1408752 21, E-Mail dluton@free.fr 
Table 1. Maternal biological variations

\begin{tabular}{lccl}
\hline & $\begin{array}{l}\text { Before } \\
\text { mifepristone }\end{array}$ & $\begin{array}{l}\text { Day 2 after oral } \\
\text { mifepristone }\end{array}$ & $\mathrm{p}$ \\
\hline Total CRH, ng/ml & $2.900 \pm 0.855$ & $2.870 \pm 0.850$ & 0.985 \\
Free CRH, ng/ml & $0.388 \pm 0.303$ & $0.500 \pm 0.326$ & 0.040 \\
Cortisol, ng/ml & $196 \pm 101$ & $439 \pm 160$ & 0.0002 \\
P, ng/ml & $95.600 \pm 54.900$ & $83.6 \pm 49.300$ & 0.001 \\
E $_{3}, \mathrm{ng} / \mathrm{ml}$ & $3.100 \pm 1.780$ & $3.580 \pm 2.040$ & 0.889 \\
DHEAS, pg/ml & $1,171 \pm 718$ & $1,552 \pm 924$ & 0.081 \\
\hline
\end{tabular}

strongly defined placental CRH as a potential peptide involved in the triggering of parturition [4]. Free CRH could be the bioavailable form which triggers parturition. This is supported by the fact that CRH receptors are present in myometrium and fetal membranes with an increasing affinity for $\mathrm{CRH}$ at the end of pregnancy. Karalis et al. [5] have shown that placental CRH expression is stimulated by glucocorticoids and inhibited by progesterone.

In vivo, a randomized placebo-controlled study with mifepristone evaluated its effects on $\mathrm{CRH}, \mathrm{ACTH}$ and cortisol levels concentrations in term pregnant women [6]. Results showed significant increase in plasma cortisol but did not found elevations in systemic plasma CRH. Contrary to Karalis's theory, this in vivo study suggested a modulation of plasmatic free CRH (f-CRH). Our objective was to focus on $\mathrm{f}-\mathrm{CRH}$ and also describe modulation of adrenal and placental steroid hormone concentrations induced by mifepristone.

\section{Material and Methods}

This was an adjuvant trial to an open study describing patterns of adrenal and placental hormone levels during human pregnancies approved by the local ethics committee. After individual informed consent, women were enrolled in the study. Termination of pregnancy (TOP) was undertaken in accordance with French legislation for various medical situations threatening fetal life or for serious pathological conditions.

The procedure consisted of the administration on day 1 of 600 $\mathrm{mg}$ of mifepristone. On day 2, depending on cervical examination and parity, cervical sticks (Laminaire ${ }^{\circledR}$, B. Braun Medical, France) were positioned, sometimes together with locally applied cervical prostaglandin gel $\left(0.5 \mathrm{mg}\right.$ of Prepidil $^{\circledR}$, dinoprostone, Pharmacia and Upjohn, Mich., USA). On day three, labor was induced by intravenous Nalador ${ }^{\circledR}$ (sulprostone, Schering SA, France) or local intravaginal Cervagem ${ }^{\circledR}$ (gemeprost $1 \mathrm{mg}$, Bellon Rhone Poulenc Rorer, France).

Venous maternal blood samples were retrieved just before administration of $600 \mathrm{mg}$ of RU486 and $48 \mathrm{~h}$ after, just prior to the induction of labor and no more than $8 \mathrm{~h}$ after local cervical prostaglandin administration when judged necessary. Blood samples were immediately centrifuged and sera were frozen immediately at $-80^{\circ} \mathrm{C}$ until assayed. All blood samples were collected at the same time of the day between 8 and 10 a.m., to limit the circadian variation of cortisol.

CRH levels were measured using the immunoassay kit CRF EIAH-8561 ${ }^{\circledR}$ (Peninsula Laboratories, Belmont, Calif., USA). The detection was performed by sequentially combining streptavidinconjugated horseradish peroxidase and 3.3',5.5'-tetramethyl benzidine dichloride. The reaction was stopped with $100 \mu \mathrm{l}$ of $2 \mathrm{~N} \mathrm{HCl}$ and the absorbance was red at $450 \mathrm{~nm}$. Standards and samples were measured in duplicate. Total CRH levels were measured directly in serum samples and after dilution 1/10 in the assay buffer. Free CRH was measured in the supernatant after ultrafiltration (Centrifree YM-30 ${ }^{\circledR}$, Amicon Millipore, Colo., USA). Sensitivity was $0.05 \mathrm{ng} / \mathrm{ml}$ and the interassay coefficient of variation was $10.9 \%$. The efficiency of the separation was checked by immunoprecipitation and was $89 \pm 7 \%$. Progesterone and cortisol were determined using the chemiluminescent immunoassay analyzer ACS-180SE system ${ }^{\circledR}$ (Bayer Diagnostics, Westwood, Calif., USA). DHEAs and unconjugated estriol were measured using isotopic immunoassays (DHEA sulphate, Beckmann Immunotech, France; unconjugated estriol Amerlex, Amersham Pharmacia Biotech).

Hormone results are expressed as mean $\pm \mathrm{SD}$, and median for age of the women, parity and gravidity. Comparisons were analyzed with the two-sided Wilcoxon test ( $\mathrm{p}<0.05$ considered statistically significant). The analysis was performed using the Graphpad Prism 5.0 (Macintosh version, GraphPad Software, Calif., USA).

\section{Results}

Twenty-six women $(\mathrm{G} 2[1 ; 13], \mathrm{P} 1[1 ; 7])$ were enrolled in the study at $24.9 \pm 5.26$ weeks of gestation and delivered at $31[22 ; 41]$ weeks of gestation. Major causes of TOP were CNS malformation or genetic diseases (CNS $(n=8)$, urinary tract $(\mathrm{n}=5)$, cardiac $(\mathrm{n}=2)$, polymalformation syndrome $(\mathrm{n}=2)$, chromosomal or genetic abnormalities $(n=7)$, infectious disease $(n=1)$ and PROM $(n=1))$. The fetus weighted $920 \pm 750 \mathrm{~g}$ at delivery. All patients had a normal vaginal delivery after induction by prostaglandin.

Plasmatic $\mathrm{CRH}$ concentration did not change after mifepristone absorption $(2.870 \pm 0.850$ vs. $2.900 \pm$ $0.855 \mathrm{ng} / \mathrm{ml}, \mathrm{p}=0.985)$, but $\mathrm{f}-\mathrm{CRH}$ increased significantly $(0.500 \pm 0.326$ vs. $0.388 \pm 0.303 \mathrm{ng} / \mathrm{ml}, \mathrm{p}=0.040)$ (table 1).

Progesterone levels were significantly decreased (83.6 \pm 49.3 vs. $95.6 \pm 54.9 \mathrm{ng} / \mathrm{ml}, \mathrm{p}=0.001$ ) (table 2). Estriol concentration was slightly increased $(3.580 \pm 2.040$ vs. $3.100 \pm 1.780 \mathrm{ng} / \mathrm{ml}, \mathrm{p}=0.089)$ and the $\mathrm{P} / \mathrm{E}_{3}$ ratio was decreased (26.9 \pm 15.7 vs. $40.7 \pm 31.1, \mathrm{p}=0.004$; fig. 1$)$. 


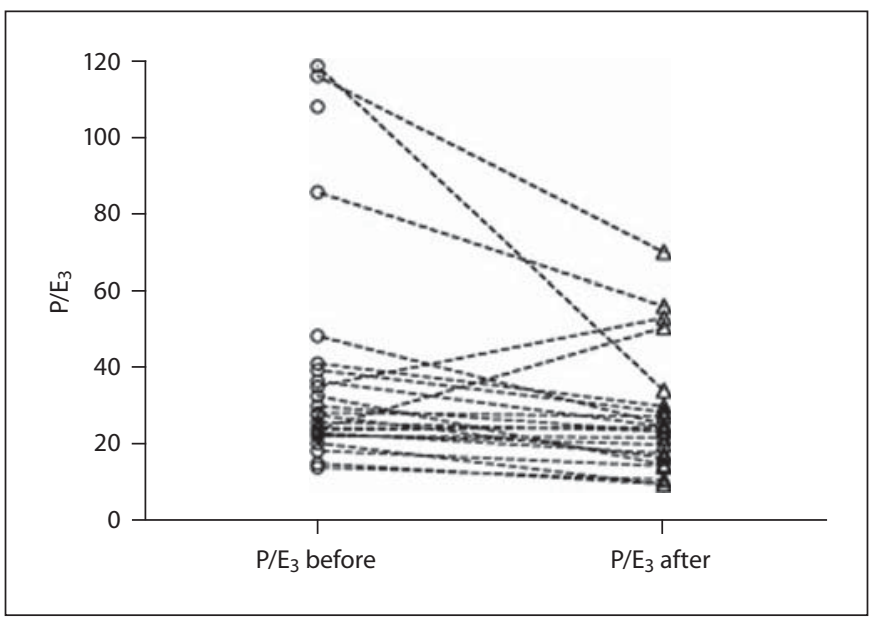

Fig. 1. $\mathrm{P} / \mathrm{E}_{3}$ ratio variation after mifepristone ( $40.7 \pm 31.1$ vs. 26.9 $\pm 15.7 ; \mathrm{p}=0.004$, Wilcoxon test)

The patient with preterm rupture of membranes at 18 weeks showed the lowest concentration of progesterone, $34 \mathrm{ng} / \mathrm{ml}$, just before the cervical ripening by mifepristone. Cortisol and DHEAs were elevated over baseline but it was only significant for cortisol $439 \pm 160$ vs. 196 $\pm 101 \mathrm{ng} / \mathrm{ml}$ respectively $(\mathrm{p}=0.0002)$.

Thirteen venous cord blood samples were obtained at delivery. Table 2 gives the characteristics of fetal blood samples. There was a strong association between maternal and fetal free CRH $\left(\mathrm{r}^{2}=0.675, \mathrm{p}=0.001\right)$, cortisol $\left(\mathrm{r}^{2}=0.570, \mathrm{p}=0.019\right)$, and a positive but modest correlation for progesterone $\left(\mathrm{r}^{2}=0.341, \mathrm{p}=0.046\right)$ and estriol $\left(\mathrm{r}^{2}=0.379, \mathrm{p}=0.025\right)$ levels. Paired $\mathrm{P} / \mathrm{E}_{3}$ ratio was also significant $\left(\mathrm{r}^{2}=0.376, \mathrm{p}=0.026,95 \%\right.$ CI $\left.0.139-1.79\right)$. We observed higher concentrations of progesterone and estriol in venous fetal blood samples of, respectively, 3.756and 2.416-fold. Figure 2 shows the positive association between paired fetal and maternal f-CRH levels.

\section{Discussion}

This study was the first to analyze the effect of mifepristone on free $\mathrm{CRH}$ and the bioavailable in vivo $\mathrm{CRH}$. According to previous publications, $\mathrm{CRH}$ is clearly implicated in the placental hypothalamic-pituitary-adrenal axis $[7,8]$. The main goal of this axis is to induce, before the onset of labor, a shift of progesterone towards estradiol production which in turn will mediate some of the known events leading to or preparing for parturition. In a large cohort of 500 women, Smith et al. [9] found a rap-

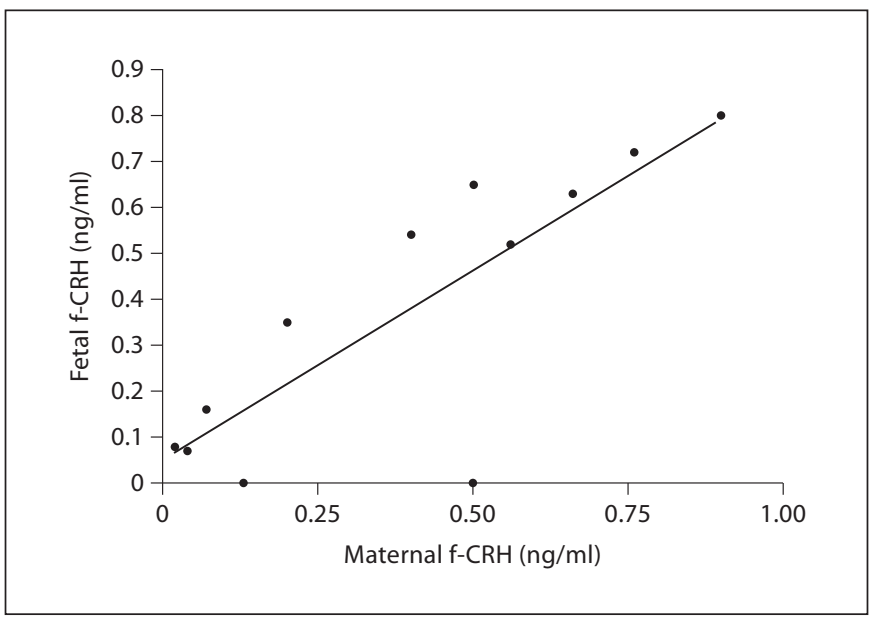

Fig. 2. Paired fetal and maternal free CRH levels $\left(\mathrm{r}^{2}=0.675, \mathrm{p}=\right.$ $0.001,95 \%$ CI $0.422-1.23$ )

Table 2. Fetal biological variations $(n=13)$

\begin{tabular}{lcl}
\hline & $\begin{array}{l}\text { Fetal venous } \\
\text { BS at delivery }\end{array}$ & $\begin{array}{l}\text { Correlation with mater- } \\
\text { nal blood sample }\end{array}$ \\
\hline Total CRH, ng/ml & $3.48 \pm 1.07$ & $\mathrm{r}^{2}=0.0016 ; \mathrm{NS}$ \\
Free CRH, ng/ml & $0.377 \pm 0.301$ & $\mathrm{r}^{2}=0.675 ; \mathrm{p}=0.001$ \\
Cortisol, ng/ml & $102 \pm 109$ & $\mathrm{r}^{2}=0.570 ; \mathrm{p}=0.019$ \\
$\mathrm{P}, \mathrm{ng} / \mathrm{ml}$ & $314 \pm 186$ & $\mathrm{r}^{2}=0.341 ; \mathrm{p}=0.046$ \\
$\mathrm{E}_{3}, \mathrm{ng} / \mathrm{ml}$ & $8.65 \pm 6.84$ & $\mathrm{r}^{2}=0.379 ; \mathrm{p}=0.025$ \\
DHEAS, $\mathrm{pg} / \mathrm{ml}$ & $2,271 \pm 934$ & $\mathrm{r}^{2}=0.008 ; \mathrm{p}=0.796$ \\
\hline
\end{tabular}

NS $=$ Non significant.

id rise of $\mathrm{CRH}$ in late pregnancy associated with an $\mathrm{E}_{3}$ surge and altered $\mathrm{P} / \mathrm{E}_{3}$ ratio. The action of mifepristone seems to mimic this onset of labor.

We observed in vivo that administration of mifepristone enhanced a shift of free CRH in the maternal circulation. These results are consistent with those of Karalis et al. [5] who demonstrated in vitro that the administration of mifepristone to primary cultured trophoblastic cells triggered the production of CRH mRNA. Yang et al. [10] showed on Percoll-purified placental trophoblasts that $\mathrm{CRH}$ has an inhibitory effect on progesterone production via a phospholipase C-protein kinase $\mathrm{C}$ signal pathway.

The discrepancy between free $\mathrm{CRH}$ and total CRH may also reflect the action of mifepristone on CRH-BP which may differ from that on $\mathrm{CRH}$ expression. It has been shown that women who have preterm delivery or 
preeclampsia have elevated $\mathrm{CRH}$ and lower CRH-BP compared to low risk pregnant women [3]. The fact that we and other authors have observed no relevant variation in total CRH during mifepristone administration may reflect the limits of the CRH measurement techniques used by immunohistologic methods.

To explore the possible mechanisms involved, we measured placental and adrenal steroid levels in maternal blood. We have shown a significant decrease of progesterone during mifepristone administration with a parallel shift of f-CRH levels. Along with the concomitant augmentation of cortisol, our results support the validity of the placental hypothalamic-pituitary-adrenal axis theory in the triggering of human parturition.

Hill et al. [11] were the first to describe the effects of mifepristone on fetal plasma steroid concentrations in mid-pregnancy. They found in paired maternal and fetal blood samples a higher fetal progesterone concentrations and an higher plasmatic maternal cortisol. During an in vivo study fetal samples were collected by cordocentesis between 20 and 33 weeks of gestation and matched maternal samples were taken at the same time [12]. At term the maternal and the fetal CRH-BP concentrations decreased significantly. Gitau et al. [13] studied the effect of acute stress caused by invasive procedures on fetal plasma concentrations of $\mathrm{CRH}$. They compared paired fetal and maternal samples and confirmed that fetal plasma CRH may be derived from the placenta. The importance of the fetal adrenal has also recently been highlighted by the study of O'Sullivan et al. [14] who showed that fetuses suffering from congenital adrenal hyperplasia were more likely to have prolonged gestation. Mifepristone may have an effect on fetal adrenal gland. While adding original data to the comprehension of parturition, our results should, however, be confirmed by studies on a larger scale.

\section{Conclusion}

In conclusion, mifepristone has an effect on free $\mathrm{CRH}$ level and change the estriol progesterone balance. Further studies are necessary to explore a potential effect on expression of CRH-BP.

\section{Acknowledgments}

We are indebted to Martine Savary and Laurence Protin for their continuous assistance. We are also indebted to the midwives, nurses and medical staff of the Department of Obstetrics and Gynecology at the Robert Debré Hospital. Part of this work was funded by a grant from the Direction de la Recherche Clinique (Assistance Publique-Hôpitaux de Paris) Contrat Recherche Clinique No. 96038.

\section{Disclosure Statement}

None of the authors have a conflict of interest to disclose.

\section{References}

1 Smith R, Smith JI, Shen X, Engel PJ, Bowman ME, McGrath SA, Bisits AM, McElduff P, Giles WB, Smith DW: Patterns of plasma corticotrophin-releasing hormone, progesterone, estradiol and estriol change and the onset of human labor. J Clin Endocrinol Metab 2009;94:2066-2074.

- Wetzka B, Sehringer B, Schafer WR, Biller S, Hor C, Benedek E, Deppert WR, Zahradnik HP: Expression patterns of CRH, CRH receptors, and CRH binding protein in human gestational tissue at term. Exp Clin Endocrinol Diabetes 2003;111:154-161.

- 3 Hobel CJ, Arora CP, Korst LM: Corticotrophin-releasing hormone and CRH-binding protein. Differences between patients at risk for preterm birth and hypertension. Ann NY Acad Sci 1999;897:54-65.

-4 Linton EA, Perkins AV, Woods RJ, Eben F, Wolfe CD, Behan DP, Potter E, Vale WW, Lowry PJ: Corticotropin releasing hormonebinding protein (CRH-BP): plasma levels decrease during the third trimester of normal human pregnancy. J Clin Endocrinol Metab 1993;76:260-262.
5 Karalis K, Goodwin G, Majzoub JA: Cortisol blockade of progesterone: a possible molecular mechanism involved in the initiation of human labor. Nat Med 1996;2:556-560.

-6 Byrne JD, Wing DA, Fraser M, Fassett MJ, Goodwin TM, Challis JR: Mifepristone: Effect on plasma corticotropin-releasing hormone, adrenocorticotropic hormone, and cortisol in term pregnancy. J Perinatol 2004; 24:416-420.

7 Ochedalski T, Lachowicz A: Maternal and fetal hypothalamo-pituitary-adrenal axis: different response depends upon the mode of parturition. Neuro Endocrinol Lett 2004;25: 278-282.

$\checkmark 8$ Smith R, Nicholson RC: Corticotrophin releasing hormone and the timing of birth. Front Biosci 2007;12:912-918.

9 Smith R, Smith JI, Shen X, Engel PJ, Bowman ME, McGrath SA, Bisits AM, McElduff P, Giles WB, Smith DW: Patterns of plasma corticotropin-releasing hormone, progesterone, estradiol, and estriol change and the onset of human labor. J Clin Endocrinol Metab 2009;94:2066-2074.
10 Yang R, You X, Tang X, Gao L, Ni X: Corticotropin-releasing hormone inhibits progesterone production in cultured human placental trophoblasts. J Mol Endocrinol 2006; 37:533-540.

11 Hill NC, Selinger M, Ferguson J, MacKenzie IZ: The placental transfer of mifepristone (RU 486) during the second trimester and its influence upon maternal and fetal steroid concentrations. Br J Obstet Gynaecol 1990; 97:406-411.

12 Perkins AV, Wolfe CD, Eben F, Soothill P, Linton EA: Corticotrophin-releasing hormone-binding protein in human fetal plasma. J Endocrinol 1995;146:395-401.

13 Gitau R, Fisk NM, Glover V: Human fetal and maternal corticotrophin releasing hormone responses to acute stress. Arch Dis Child Fetal Neonatal Ed 2004;89:F29-32.

14 O'Sullivan J, Iyer S, Taylor N, Cheetham T: Congenital adrenal hyperplasia due to 21-hydroxylase deficiency is associated with a prolonged gestational age. Arch Dis Child 2007; 92:690-692. 